\title{
Analysis of Development Pattern for Higher Education
}

\author{
Lichun Niu, a and Miao Shang ${ }^{2, b}$ \\ ${ }^{1}$ Xijing University, Shaanxi Xi'an, China \\ ${ }^{2}$ Mechanical and electrical technology department, Xijing University, Xi'an, China \\ a815765002@qq.com, b445700839@qq.com
}

Keywords: Higher education; Development model; Output mode; Internal cooperation mode; Transnational education

\begin{abstract}
With the rapid development of global economy, the meaning of higher education is highlighted in economy and politics, etc., Transnational higher education as a new mode of emerging, and the development of higher education has obtained the breakthrough. Among them, the direct output module has received the higher education of the developed countries and regions. Drives the output mode and cooperative input mode which become the main mode of transnational higher education development for the emerging or developing countries. In this article, the direct output mode is illustrated for country with a highly developed in economy, education. The application of Internal cooperation mode is studied in emerging and developing countries; Internal cooperation pattern is specific analysis about the ec development. Detailed analysis of the development of higher education mode is of great significance for promoting the further development of our country's higher education and the development of transnational education.
\end{abstract}

\section{Introduction}

At any time, the rapid development of the global economy in higher education, economic and political aspects of the significance of the increasingly obvious. The higher education in China including college in university and college graduate, and staff University, Central Radio and TV University. All along, both developed and developing countries are to achieve their specific higher education policy objectives, thereby resulting in a different development philosophy and value orientation. Each country and region in accordance with their development philosophy and value orientations different, in tertiary education is bound to brighten up the different development strategies and development models [1]. Transnational higher education as a growing emerging new mode to enable States a breakthrough has been made in higher education development. In conjunction with the development of the countries of the characteristics, the development of higher education mode can be summarized in four, namely direct output mode, internal consolidation of co-operation, to enter the output mode , co-input mode. Where direct output template some higher education for the developed countries and regions. To enter the output mode, co-input mode, and they became a new or developing countries the development of higher education in transnational main mode.

\section{Analysis of Direct Output Mode}

The direct output mode have been affected by the economic, education of highly developed countries. In emphasizing the economic gains and to obtain access to human resources as the value orientation of the countries and regions that direct output mode is used. By virtue of its economic benefits, academic advantages, language and technical benefits of the advantage, in their own form of higher education is very strong output capability.

With the expansion of the higher education of their domestic and public finance on higher education into the compression, Governments have begun to put the expansion of student enrolment as a solution to the financial crisis of the higher education means. In the ensuing transnational higher education in the development process, gradually perfect the economic benefits of the development 
concept [2]. Through the development of Transnational Education emphasized in opening new markets and expanding the channels for overseas students to increase the share of the international market in order to increase their export earnings and enrich the national higher education institutions are a source of revenue for the government make up for the inadequacy of funding for education. The economic benefits of the development philosophy of the impact of the "knowledge into a new commercial transactions. The University had to be more like a commercial organization rather than educational institutions to think about it. In on century 80's, England starts to the foreign student to adopt the collection "the sum total cost school expense" the policy [3]. All foreign students must pay the sum total expense, namely charges the school expense according to our country student school expense four times to the foreign student. In recent years, English Government tried hard the higher education to take one industry to the world promotion, in order to with country ' and so on US, Australia seized the foreign student market, English Government took many kinds of measures to impel the transnational higher education positively the development. The Australian Government through the lifting of foreign students in the market to allow each school to direct foreign students. In order to strengthen Australian universities in higher education.

\section{Internal Cooperation Model Analysis}

Internal cooperation mode is one of the development transnational higher education the new mode. In order to tie in with the European integration process, EEC Member States Leaders Incorporating education into future consolidation among Member States [4]. Where the content associated with higher education has three: the establishment of a "joint learning project, teachers in the short-term study tours" item, educational administrators exchange project. Joint study the final goal of the project is to promote two or more members of the colleges and universities of joint work between the design of the curriculum of the development and assessment. The "joint" are mainly manifested in the course of common design, the exchange of students in institutions of learning for mutual recognition of credits, teachers exchange. Among them, the key point to encourage the three types of items: (1) Participate in the course of the pupils in cooperation with relevant institutions of learning for a certain period of time, duration of study and obtain credit. (2) Each partner universities this cooperation as part of the curriculum from another institution for teachers. (3) The course of study or disciplines with European community development are closely related [5]. In these projects, under the impetus of the participation in the project countries there has been a five categories of cooperation project: to student mobility-oriented projects, to kindergarten teachers-oriented projects, collaboration teaching modules, and joint management of projects as well as with the European affairs related to the joint study projects.

The European Common Market and the construction of constant deepening and the European single market gradually formed the backdrop of European integration of higher education in depth. The development of these projects are greatly facilitated by the European States internal college students and scholars, the transnational flow of education cooperation activities [6]. At the same time, these projects has also significantly contributed to the countries of Central and Eastern Europe of the higher education system through cooperation with the University of Western Europe and to raise the level of education and the integration with the European and International Higher Education of the latest development.

\section{To Enter with Output Mode Analysis}

To enter with output mode is emerging countries in the development of tertiary education is transnational a mode. In the mid-1990s, transnational higher education was the introduction of Malaysia is active. At the time of economic recession in Malaysia, makes it possible to the number of students studying abroad the Tai Fook decrease, while domestic public universities, combined with the lack of capacity of education policy reform and education to the needs of the mass of the Government with the past of private tertiary institutions established by the stringent attitudes and 
prejudices, adapt to changes in the international and domestic situation, domestic policy has accordingly made the adjustments and reforms in order to more open policies to promote private higher education development [7].

Singapore as a human and natural resources are relatively hiding and left a low birth rate in the emerging countries in the implementation of an outward-oriented economic development strategy on the basis of adherence to a comprehensive open education international policies [8]. The Government of Singapore at cross-century strategy for the new starting point for the development of higher education made clear in the internationalization of the strategy, the government through scholarships and after graduation working in Singapore and other means actively attract around the world, especially the countries of the region is the Southeast Asian students. The Government of Singapore in 1998 declared the decade of the top universities plan" and positive developments in the international trade in education services, the concept of the establishment of the economic development board, tourism authority, the company registration authority, the Ministry of Education, local tertiary institutions comprising the development of higher education in transnational mechanisms in various sectors within the limits of its responsibilities in the promotion of the development of higher education in transnational Singapore. At the same time, the Government of Singapore has also promoted local educational institutions and education institutions go out of the country, a wide range of recruitment of students in different countries of the asia pacific region, the Singapore development to become a "regional center for higher education". The Singapore government in order to safeguard the project and the movement of people, it also announced a simplification of visa procedures, allow minor students parents accompany read, allows reasonable wage earners, the provision of government subsidies, scholarships, student loans, foreign talent housing schemes such as the preferential policies [9]. Through their efforts, Singapore at the introduction of a world-class university had achieved impressive results. With the United States, France, such countries as Germany and the Netherlands 15 colleges and universities in Singapore campuses in these state-of-the-art colleges and universities are mostly established the foreign students.

\section{Analysis of Development Model of China's Higher Education}

Cooperation mode has promoted the development of higher education in our country. Transnational higher education is our tertiary institutions internationalization of a concrete practice. In order to adapt to the needs of accession to the WTO, the strengthening of the activities of the transnational higher education planning and management, my country in September 2003. The official promulgation of the People's Republic of China Sino-foreign co-sponsoring Ordinance. To ensure that the regulations follow-up on the implementation of the Ministry of Education in June 2004 announced the "Implementation Methods for the implementation of the Ordinance. The relevant provisions of the Ordinance is to have an additional and improved. These is a sino-foreign cooperative activities of the school provided a basis for further and policy guidance. The Ordinance expressly provides: foreign educational institutions with the China Education Institutions to cooperate in the establishment of a sino-foreign cooperative or organize the educational bodies or sino-foreign co-sponsoring projects and to Chinese citizens as the primary enrolment object. The Ordinance also further clarified the implementation of the public good, determine its status as an integral part of the cause of China's education [10]. The state of the implementation of the expanded into school, specifications and management according to law, promote development approach. The state in the field of higher education and vocational education by introducing foreign high-quality education resources, especially with the famous foreign institutions of higher education development in the implementation of priority development encouraged and attitude. 


\section{Conclusion}

For a long time, both developed countries and developing countries, countries are hope through the higher education to achieve its specific policy goals, thus formed the different development idea and value orientation. Every country and region according to their different ideas and value orientation of development, in the higher education is bound to the quantitative different development strategies and development models. Transnational higher education as a new mode of emerging, make the development of higher education has obtained the breakthrough. Combining with the characteristics of national development and national higher education development mode can be summarized into four kinds, namely direct output mode, internal integration cooperation mode, drive the output to input mode, collaborative input mode. Among them, the direct output module has received the higher education of the developed countries and regions. Drive the output to input mode, collaborative input mode, and they become the emerging or developing countries the main mode of transnational higher education development. In this article, direct output mode about the economy, education is highly developed countries are described; Internal cooperation mode of application were studied in emerging and developing countries; Internal cooperation pattern is specific analysis about the ec development. Detailed analysis of the development of higher education mode is of great significance for promoting the further development of our country's higher education and the development of transnational education.

\section{References}

[1] X.J.Guo: Transnational Education Development Concept and Strategy (Stanford university press, China, 2008)

[2] J.B.Wang, H.T.Yang::New Field of Overseas Investment-New Trend of Transnational Higher Education (DongYue Review, China, 2012)

[3] B.C.Ji:Our Country's Higher Education Scale Forecast Analysis in 2020, Vol. 1 (2011) No. 1, p. 305.

[4] H.Y.Liu: U DP Proportion Higher Education and Social Policy Research, Vol. (2012), P. 27-28.

[5] L.J.Guo: Under Globalization of Transnational Higher Education-Point of View, Problems and China's Response (China Social Sciences Press, China, 2009)

[6] G.P.Feng: Transnational Education-International Comparative Study (Shanghai People's Publishing House, China ,2010)

[7] Benoit Minogue: Higher Education Spending and Output-Complexity of Relationship, Peking University Education review, Vol. 2 (2013), 60.

[8] Henry m. levin. Education How to Adapt to Future-Background of American Education, Peking University Education Review, Vol. 2 (2013), p. 2-3.

[9] Y.L.Xie: Soul of European Universities Classification, Comparative Education Research, Vol.4 (2010), p. 45.

[10] G.S.Yi: University Chinese-Foreign Cooperation in Running Schools Mode and Operation Mechanism of Research (Shanghai University Publishing House, China 2007.) 